\title{
Traditional Adaptation Strategies to Hydrosystem Degradation for Sustainable Management of the Aheme Lake in Benin (West Africa)
}

\section{Amoussou Ernest (Ma)}

Department of Geography, University of Parakou, Benin, Parakou, Benin, Laboratory Pierre PAGNEY, Climate, Water, Ecosystem and Development (LACEEDE)

\section{Totin V. S. Henri (Ma)}

Department of Geography, University of Parakou, Benin, Parakou, Benin, Laboratory Pierre PAGNEY, Climate, Water, Ecosystem and Development

$$
\text { (LACEEDE) }
$$

Tohozin Yves Antoine (Mc)

Department of Geography, University of Abomey-Calavi,

Oyede M. Lucien (Professor)

Earth Sciences Department, University of Abomey-Calavi,

\section{Boko Michel (Professor)}

Laboratory Pierre PAGNEY, Climate, Water, Ecosystem and Development

$$
\text { (LACEEDE) }
$$

University of Abomey-Calavi, Jéricho, Cotonou, Bénin.

\section{Abstract}

The water system like the lake Aheme are abundant in halieutic species (fish, crabs, shrimps...) exploited by resident populations. Over exploitation and high degradation of ecosystems of the lake Aheme induce inexorably fish productivity reduction. Halieutic production reduction generates a subsequent fall of incomes of the households depending primarily on the fishery activities. The fall of halieutic production involves today significant migratory movements of the fishermen and socioeconomic problem. Thus, adaptation strategies are developed for sustainable management of the lake Aheme. These strategies consist in holding as sacred a part of the lake with the divinity Avlekete, fishing holes creation and mangrove restoration. Sacred lake park called 'Avlekete-tin"' is the most important traditional strategy. These endogenous methods of ecological conservation constitute actually effective strategies of productivity and fishing development on the Aheme lake. 
Keywords: Benin, Aheme lake, Avlekete-tin, Fishing, Ecological conservation

\section{Introduction}

Since the Seventeen centuries and especially because mixing Europeans, littoral area which concerns the lake Aheme prospered and attracted many continental populations. The outstanding historical event which started pressure on the ecosystems of the lake Aheme were initially population migration and occupation around the water system, both moults by economic exploitation of natural resources.

In the study area, previous structures of political and religious organization are based on the traditional worship. This pledge of local resources management on homogeneous community is disrupted (Pliya, 1980). Population growth, economic expansion especially trade development lead to fish resources disproportionate exploitation in the Aheme lake.

Sustainable management of fishing requires halieutic resources productivity and species conservation strategies development in the Aheme lake area.

\section{I.}

\section{Geography of the Aheme lake}

The Aheme lake, situated in the south-west of Benin is an ecosystem located in the wet tropical zone between $6^{\circ} 20^{\prime}$ and $6^{\circ} 40^{\prime}$ of northern latitude and $1^{\circ} 55^{\prime}$ and $2^{\circ} 00^{\prime}$ of east longitude (figure 1 ). 


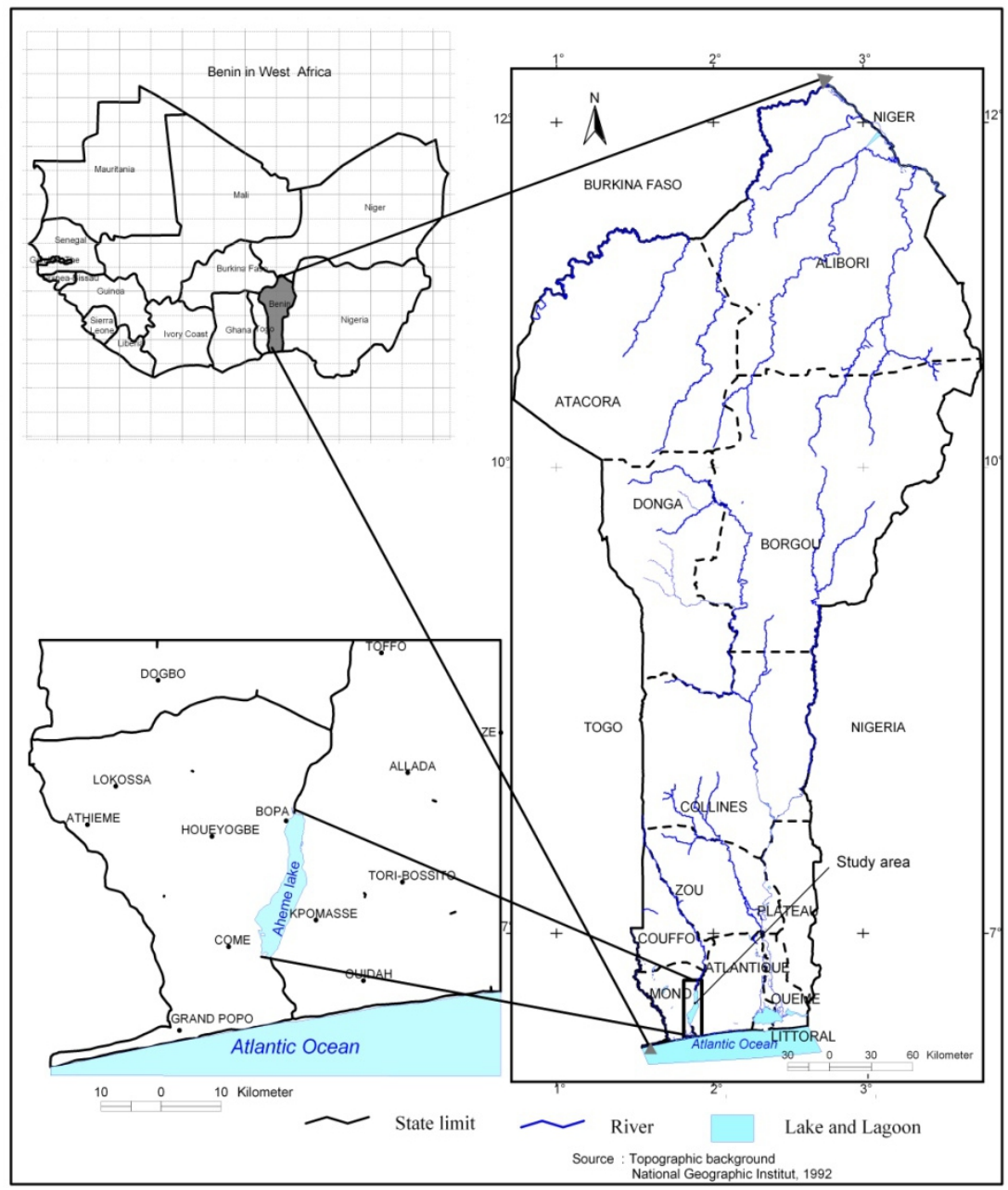

Fig. 1: Location of Aheme lake in South-West of Benin

A project of the Aheme lake and mangrove rehabilitation and policies of rational management capacity building covering three years will allow especially follow-up and strengthen efficient traditional strategies developed by residents population.

Covering an average surface of $85 \mathrm{~km}^{2}$ (Oyédé, 1983) the Aheme lake is a maximum depth $2.35 \mathrm{~m}$ and $24 \mathrm{~km}$ length (Agonsa-Dohi) with an average width of $3.4 \mathrm{~km}$. It is hydrologically connected with the Couffo River upstream and the Atlantic ocean, the Mono River and the coastal lagoon by the means of the Aho channel downstream. This ecosystem is located between two plateaus of which altitude is $100 \mathrm{~m}$ in East and $30 \mathrm{~m}$ in West (Amoussou, 2003).

Recent population density (175.66 hab/ $\left./ \mathrm{km}^{2}\right)$ in 2002 is falling compared to that of 1986 (200 hab/ $\mathrm{km}^{2}$ ) because of fishing activities 
reduction. Local socioeconomic activities contribute to destruction of mangroves forest used for fishing techniques called acadja and salt preparation. The municipalities around the Aheme lake are Bopa, Kpomasse, Come, Grand-Popo and Ouidah. However the Aheme lake is administered by the traditional chief and the local authorities and the Governmental Fishing Direction.

\section{Data and method}

Methodological approach consists in use of the model DPSIR which means Directives, Pressure, State, Impact and Responses as showing by diagram 1.

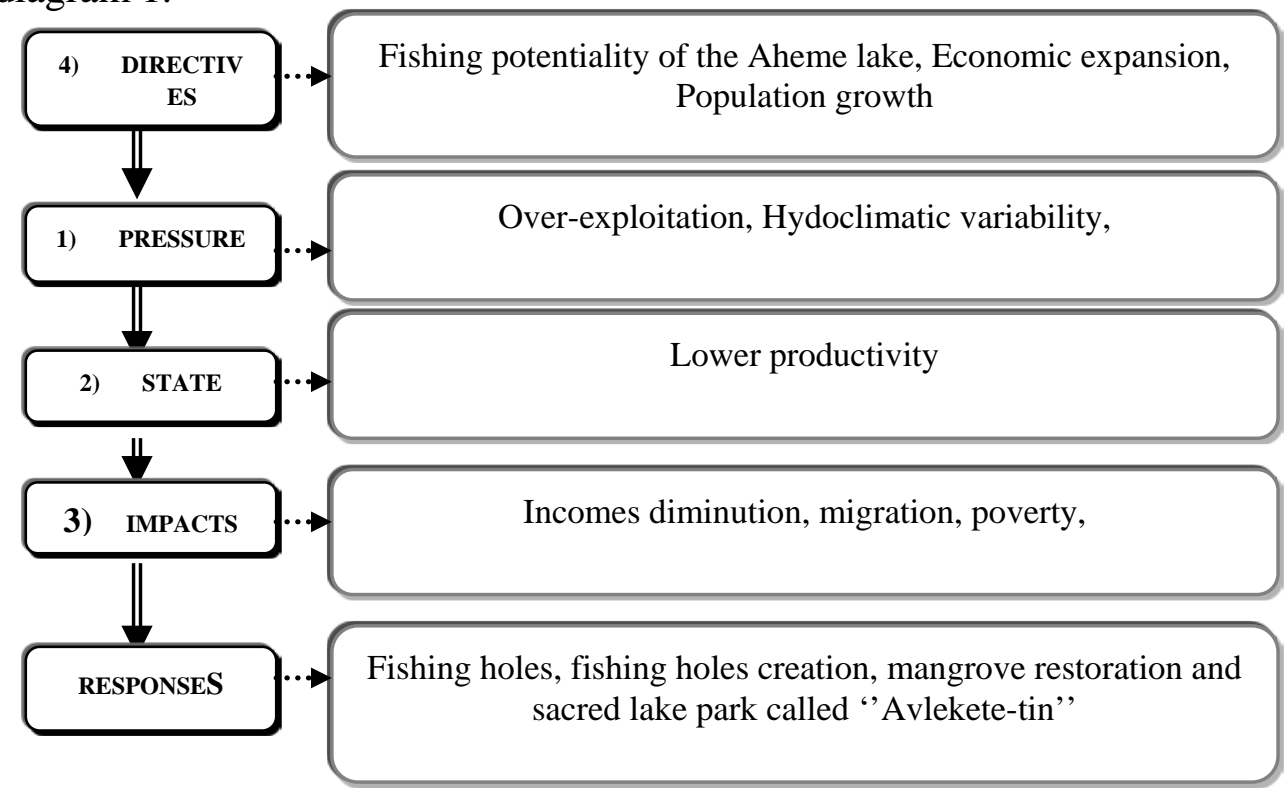

Diagram 1. Concept of the Aheme lake sustainable management strategies with the model DPSIR (Source: Amoussou, 2003)

This model helps to develop action plans to reduce the Aheme lake degradation and to increase fish productivity. This approach is completed by hydroclimatic variability analysis with climate and hydrology data over the period 1965-2004, and by physic parameters (salinity and temperature). Moreover, field direct observations lead to collect indicators of environmental components changes and their implications on the lake.

In frame of work research, for strengthen management capacity of the fishermen, local authorities, workshop was organized and supported by stakeholders of Beninese Agency for Environment, Regional Centre of Agricultural Production. The objectives of the previous and next training 
workshop are to build capacity of fishing actors in mangroves restoration, avlekete-tin efficient management in the Aheme lake.

\section{Results and discussions}

\section{Factors of halieutic resources spatial and temporal distribution}

Hydrological variability of the Aheme lake is related to displacement of the West African Monsoon and the rainy phenomena associated during the year (Amoussou et al., 2004). Monthly rainwater and surface water which contribute to Aheme lake water availability is illustrated by figure 2 .

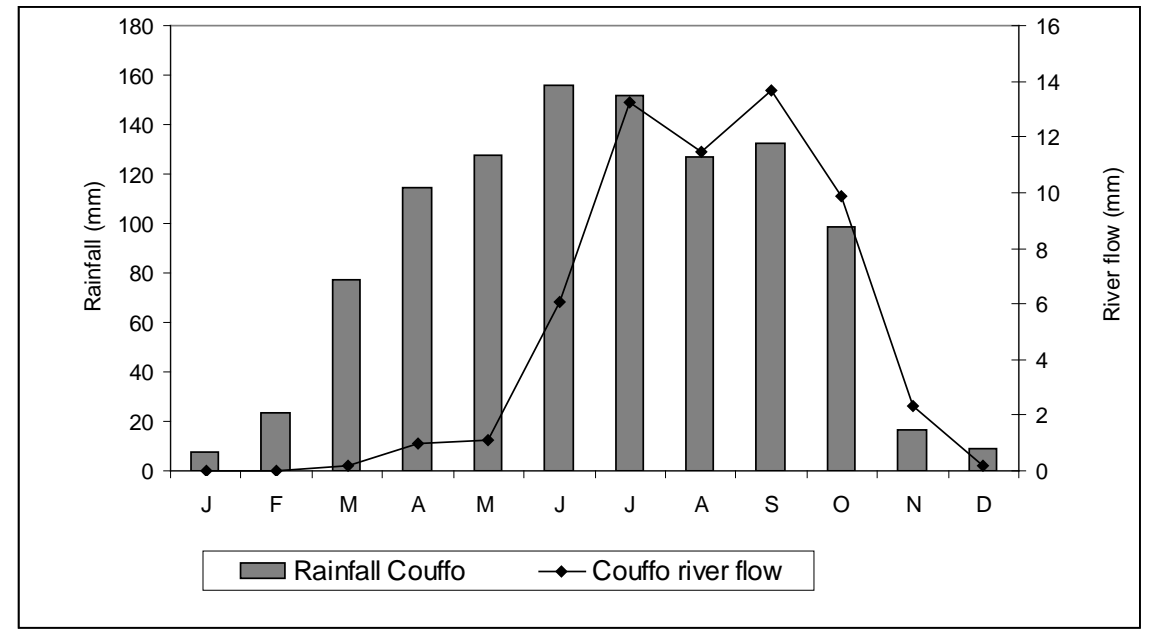

Fig. 2. Monthly distribution of rainfall and river flow in the area of the Aheme lake

The Aheme lake is dependent on rainfall and Couffo river flow from May to October corresponding to the wet period while November to March is the dry season in the south of Benin. Indeed, area of the Aheme lake covers $100 \mathrm{~km}^{2}$ in the highest water level and $70 \mathrm{~km}^{2}$ in the lowest period (dry season).

The lake is affected in the lowest water period by saltwater intrusion which induces increase of salinity rate. The physical parameters measure at mean stations across the lake and particularly at the station of Guezin, hydrological crossroads of marine (ocean Atlantic and Aho channel) and freshwater (Aheme lake and River Couffo) show variation of salinity rate between 0.01 to $7 \mathrm{~g} / \mathrm{l}$ and of temperature from 25 to $33^{\circ} \mathrm{C}$ (figure 3). 

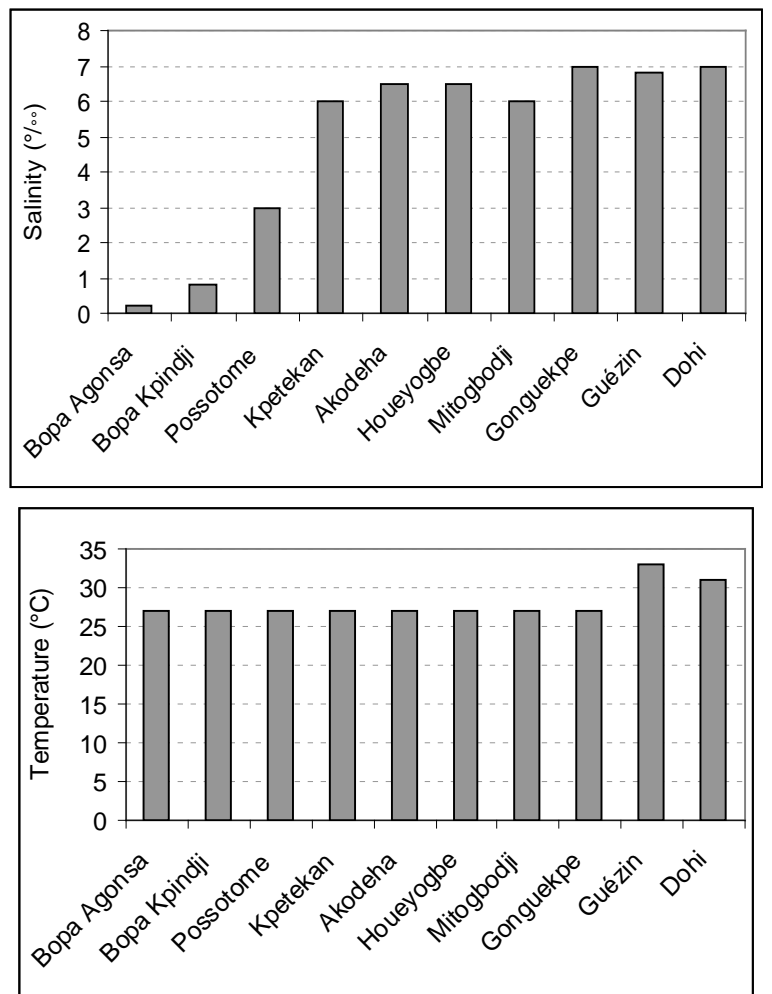

Fig. 3. Salinity and temperature spatial variability in the Aheme lake

Hydroclimatic variability combined physical parameters seasonal variation influence fish species growth and consequently halieutic productivity caused by acceleration of chlorophyllian synthesis of the Aheme lake microflora. According to Pliya (1980), fish species like Penaeus duorarum, Cassostrea gasar reproduction are influenced by all these parameters. In reality, fish species in this lake are composed as showing by table 1.

Table 1. Fish fauna composition in the water system coastal lagoon-channel Aho-Aheme lake

\begin{tabular}{|c|c|c|c|}
\hline Families & Race & Species & $\begin{array}{c}\text { Indigenous names in } \\
\text { Mina, Pédah or Xwla }\end{array}$ \\
\hline Carangidae & Caranx & Hippos & Kpankpan \\
\hline & Penacus & Notialis & \\
\hline & Ostria & Tulipa & Adjagoue \\
\hline & Choroscombrus & Chrysurus & Gbanmadouie \\
\hline & Scomberomorus & Tritor & Ako \\
\hline & Tetraodon & Lineatus & Ozouie \\
\hline Dasyatidae & Dasyatis & Margarita & Egban \\
\hline Elopidae & Elops & Lacerta & Ogoun \\
\hline & Sphyraena & Afra & Agnanto \\
\hline & Lutjanus & Agennes & Dayi \\
\hline & Strongylura & Senegalensis &
\end{tabular}




\begin{tabular}{|c|c|c|c|}
\hline & Pentanemus & Quinquarius & Guinlonui \\
\hline & Mugil & Cephalus & Guessou \\
\hline Channidae & Parachanna & Obscura & Hotrou \\
\hline Osteoglossidae & Heterotis & Niloticus & Houâ \\
\hline Sciaenidae & Pseudotolithus & Senegalensis & Djoké \\
\hline Polynemidae & Galeoïdes & Decadactylus & Tchicoué \\
\hline Carangidae & Caranx & Senegalensis & Pampanvi \\
\hline Dasyatidae & Dasyatis & Magarita & Ozouin \\
\hline Haemulidae & Pomadasys & Jubelini & Kokouin \\
\hline Serranidae & Epinephelus & Aeneus & Toboko \\
\hline Monodactylidae & Monodactylus & Sebae & Gandanhongui \\
\hline
\end{tabular}

Source : Lalèyè et al., (1997) et Amoussou (2003) completed by field work, 2006 et 2007

This fish potential of Aheme ecosystem is the most factors of resident population occupation and the lake resources exploitation.

\section{Exploitation of fish resources and degradation impacts in the Aheme lake}

Fishing is the mean activity in the study area with a rate of $80 \%$ of the total population. Thus to maintain their level of income, fishermen exert pressures on halieutic resources. What is called 'rationality and rural logic'. In fact, to maximize the immediate output, they use prohibited fishing machines (with fine mesh) which captures fish whose size is lower than the size of maturity. Also, there isn't fishing effort limitation. This concept applied to a halieutic stock is defined by Gortworstand Slootweg (1994) as 'the measurement of the whole captures means implemented by fishermen to this stock during an interval of given time". Field work help to know that fishermen of the localities of Vovio, Adjatokpa, Ouedeme-Pedah, Gongue make fishing activities with nets to fine mesh on average 5 to 6 hours in the lake.

Over-exploitation of fish resources lead to degradation of the Aheme lake and falling of halieutic productivity caused by reduction of the duration of species cycle of development or their migration toward over surface water system. Table 2 presents some species disappeared according to the population these two last decades.

Table 2. Some fish species disappeared from the Aheme lake

\begin{tabular}{|c|c|c|}
\hline Scientific names & Families & $\begin{array}{c}\text { Indigenous names in } \\
\text { Pedah }\end{array}$ \\
\hline Parachanna will obscura & Channidae & Hotrou \\
\hline Heterotis niloticus & Osteoglossidae & Houâ \\
\hline Pseudotolithus senegalensis & Sciaenidae & Djoké \\
\hline Galeoïdes decadactylus & Polynemidae & Tchicoué \\
\hline Caranx senegalensis & Carangidae & Pampanvi \\
\hline Dasyatis magarita & Dasyatidae & Ozouin \\
Pomadasys jubelini & Haemulidae & Kokouin \\
Epinephelus aeneus & Serranidae & Toboko \\
\hline
\end{tabular}

Source: Field work data, 2007 
The degraded state of the lake involved a fall of the products halieutics according to 95\% of fishermen. Figure 4 illustrates the tendency of fish production over 15 years.

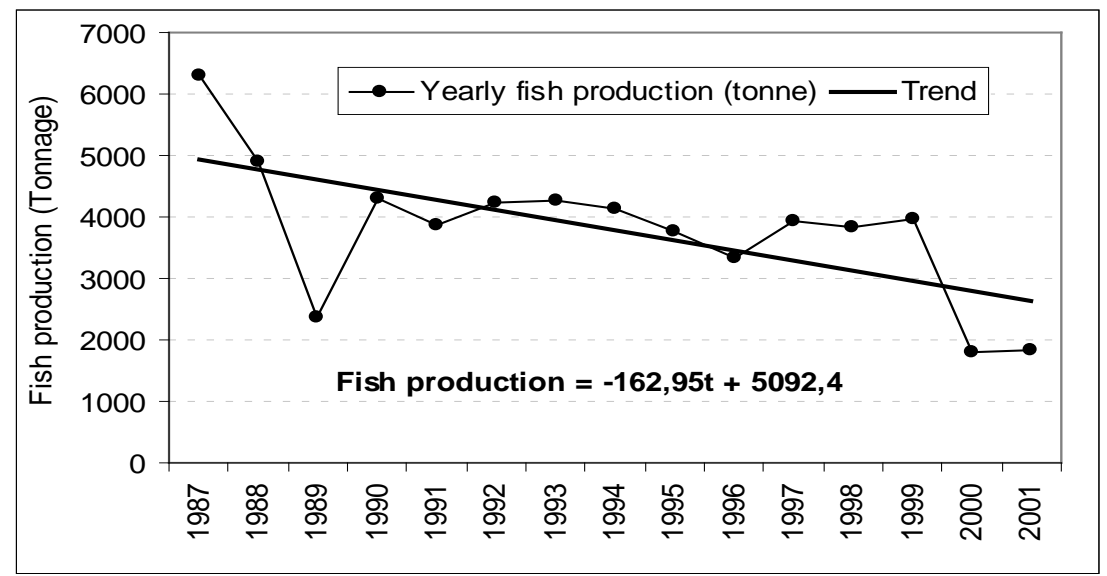

Fig. 4. Fish production in the Aheme lake (1987-2001)

Fall of fish production in the Aheme lake area is 163 tonne per year. This production trend induces reduction of the number of fishermen and of shrimp or fish tradesmen. Consequently, there is a decline in tax revenue income populations of the municipalities concerned.

Deterioration of fish stock and halieutic production is due to eutrophization (photograph 1), lake surface reduction, disappearance of mangrove forest and especially lost of halieutic diversity. But according to the resident population, endogenous factors which explain the lake degradation and fish production fall are non-respect of taboo, the ways and customs and traditional laws of water system management. These popular opinions are related to the link between physical or environmental components and tradition of cultural groups that inhabit the Aheme lake. For populations, the loss averaged forty species of fish and the production drop is the signal of a disturbance in the sacred order of the management of the lake system. These are the factors that motivate people and govern the development of traditional coping strategies for the management of Aheme lake. 


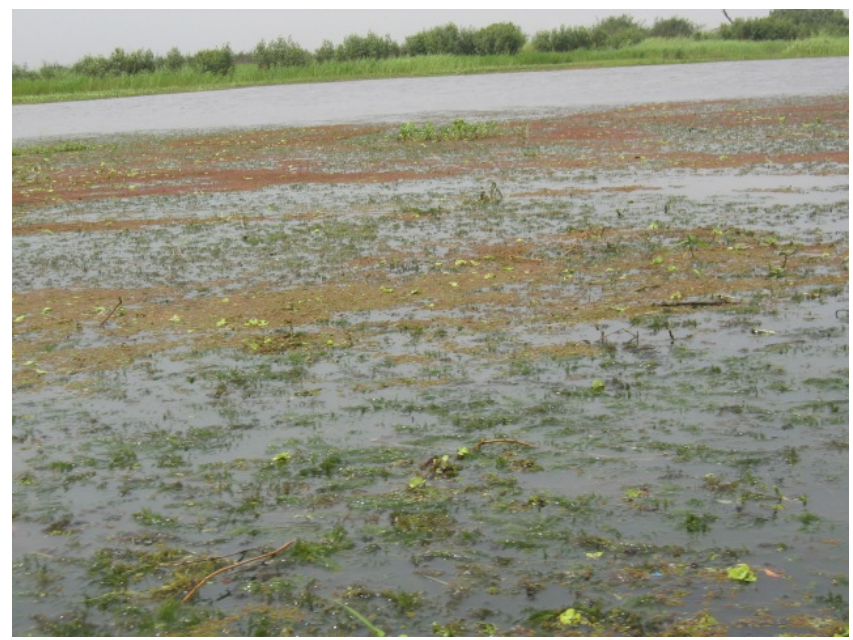

Amoussou, october 2008

Photograph 1. Eutrophization of Aheme lake

\section{Endogenous strategies of Aheme lake management}

To face Aheme lake degradation and fall of fish stock and production, people turn to the ritual and worship practices inspired from their cultural inheritance. Also, they develop techniques which consist in creation of fish holes and mangrove restoration.

\section{Vodoun, scarification worships and sustainable management of the lake}

Few villages situated all along the Aheme lake develop the strategy of sacred fish park based on the fetish Avlekete. This traditional protected park called Avleketetin constitutes one of the conservation techniques followed from ingenuity of rural population. The avleketetin disposal is illustrated by photograph 2 and 3 .

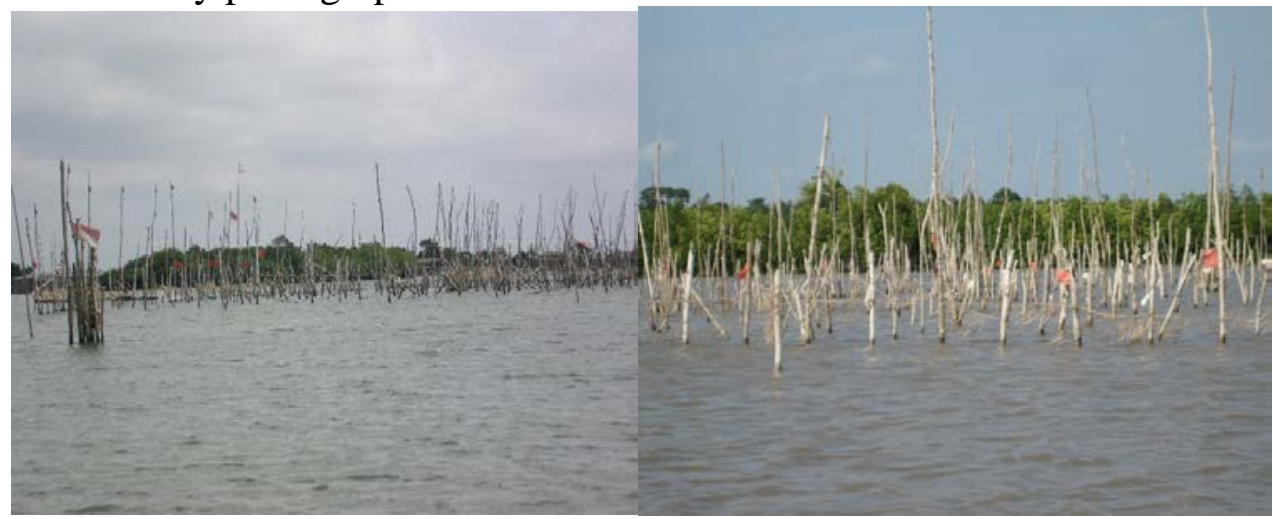

Amoussou, December 2007 and April 2008

Photographs 2 and 3. Sacred and protected park Avleketetin on the Aheme lake 
This technique helps to create protected fish Park having to allow halieutic species reproduction and development. Traditional protected park imposes to fishermen resources conservation for a possible profitable fishing. Part of the lake is sacred to cure falling of fish productivity, to allow growth and migration of mature fish in all the lake where they can be captured by any fisherman. Avleketetin identified in the Aheme lake covers an area varying between $78.5 \mathrm{~m}^{2}$ to $314 \mathrm{~m}^{2}$. Their number increases from 13 to 25 from the year 2004 to 2008 because $96 \%$ people approval of this fishing technique. However the spatial distribution shows that there is one avleketetin for two villages. This number of avleketetin is recognized by people like insufficient.

Endogenous adaptation strategies are related to turning to the occult forces via Vodoun, introduction of traditional management laws. Socioanthropological changes associated the fall of the productivity spread and request adaptive capacity of the people. The worships ritual are done in September and August when bordering populations associated to avlekete fetish followers called Avleketessi beseech divinities Adikpo, Kpinsou, Dagbohonsou, Tohagogossou, Kouffo-aho, Yete, Gboclo, etc. in the time of sacralization ceremonies. The fish park sacralization consists in choosing in front of each lake village a circular zone in which more than 200 wood stakes are planted around the fetish Avlekete in middle. This divinity is a fetish of the sect of Thunder (called Hebiosso) related to water system including lake management in the south of Benin. These ceremonies require the payment of 225,000 FCFA for the fetish and approximately 305,000 FCFA according to a diameter of the park. Fetish installation is also made with participation of governmental institutions like the Regional Centre of Agricultural Production which support financially a part of the infrastructures (purchase of wood). Each year, sacrifices rites requiring in means 187,000 FCFA are doing to Avlekete to keep fish park and increase productivity of the Aheme lake. After these sacrifices, popular ceremony called Awilé help to decree one or two week banning of fishing in the lake.

This traditional strategy which allows an ecological reconstitution of fish stock will be encouraged in the process of halieutic biodiversity conservation for a sustainable management the Aheme lake, and income increasing of the bordering populations.

\section{Fish holes and mangrove restoration}

Fish holes are traditional fish farm carried out by fishermen along the Aheme lake and in its plain of flood. These ponds have a surface varying between 20 and $30 \mathrm{~m}^{2}$ and a depth from $0.6 \mathrm{~m}$ to $2 \mathrm{~m}$. In order to improve fish productivity, fishermen implement their ingeniousness by developing 
integrated systems which consist in combined fish hole with branches (acadja) or fish hole with mangrove as illustrated by photographs 4 and 5 .

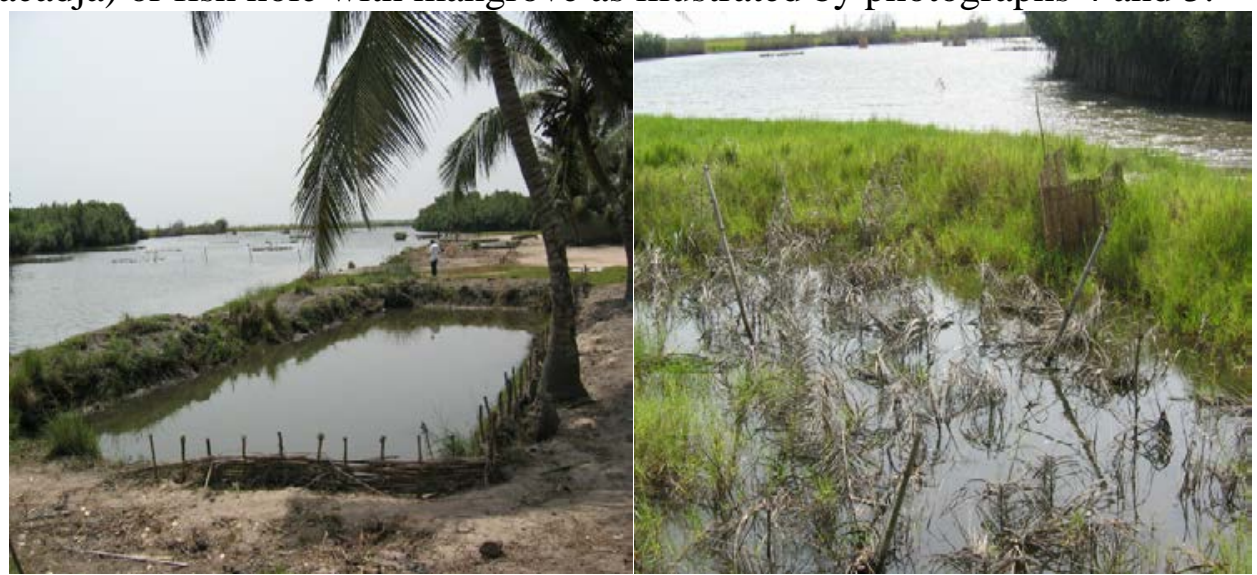

Totin, 2007

Photograph 4 and 5. Simple fish hole and integrated fishing system

The fish hole is used for fish breeding since alevin stage until mature stage. Mangrove forest restoration all along the Aheme lake would contribute to ecosystem protection, ecological restoration of fish reproduction and development zone and would favour strong halieutic productivity. According to Kestemont et al., (2007); Imorou Toko et al., (2008) the annual production of a fish hole is approximately 2.7 tonne per ha in experimental perimeter. Ecological follow-up plays a significant role in increasing output of fish farm disposal.

\section{Conclusion}

Socio-anthropological aspects of Aheme lake resources and their management are founded on the ways and customs of resident populations. Non-observance of prohibited and taboos would be the main causes of the lake degradation and halieutic productivity falling. Sociological bases and endogenous vision of the lake resources management deserve to be supplemented by a technical tools management. Sociocultural models of management developed by Pedah, Xwla and Sahoue around the Aheme lake take as a starting point the occult forces of divinities Avlekete, Adikpo, Kpinsou, Dagbohonsou, Tohagogossou, Kouffo-aho, Yètè, Gboclo. Also beliefs, rites and forbidden play an important role in the traditional strategies of Aheme lake management.

Professional restructuring of the populations especially the fishermen could also limit human pressure and overexploitation and could lead to a sustainable management of Aheme lake. To this end, job creation and financial support like micro-credit could help to reduce vulnerability of the study area. However, best knowledge of social and cultural aspects and 
capacity building and rigorous applying of positive endogenous strategies combined to modern fishing technologies will lead to an integrated and sustainable management of the Aheme lake.

\section{Acknowlegements}

The authors wish to thank the fetishist's Heads and the Representative of the management committee of the traditional protected fish park at the level of the Aheme lake.

\section{References:}

1. Adité, A. (1996). Evolution des paramètres physico-chimiques des principaux plans d'eau du sud Bénin 42p.

2. Amoussou, E. (2003). Dynamique hydro-sédimentaire et mutations des écosystèmes du lac Ahémé. Mémoire de maîtrise, DGAT / FLASH/ UAC, 103p

3. Amoussou, E., Vissin, E.W., Houssou, C.S. \& Boko, M. (2004). Changes in Physicochemical parameters and productivity of Aheme lake. In the 14th Stockholm Water Symposium: Drainage basin management-regional approaches for food and urban security. Abstract volume, 2004 Stockholm Water Symposium, pp 159-160.

4. Amoussou, E., Oyédé, L. M. \& Boko, M. (2006). Productivité biologique et gestion endogène durable du "lac" Ahémé au Bénin. In 'Climat et Développement', LECREDE/FLASH/UAC, vol. $\mathrm{n}^{\circ} 2$ pp 1-12.

5. Amoussou, E., Oyédé, L. M. \& Boko, M. (2007). Variabilité pluviométrique et flux de turbidité dans le complexe Chenal Ahô- lac Ahémé au Bénin (Afrique de l'Ouest). In Actes colloque ' 'Climat, Tourisme et Environnement', XXème colloque de l'Association Internationale de Climatologie (AIC), Carthage, Tunisie, pp 471-477.

6. Le Barbé, L., Alé, G., Millet, B., Texier, H., Borel Y. \& Gualde R. (1993). Les ressources en eaux superficielles de la République du Bénin. Edition ORSTOM; 540 p.

7. Adjanohoun, D. (1999). Les techniques de gestion des écosystèmes lacustres et péri lacustres: l'exemple des populations de pêcheurs du lac Ahémé au sud-Bénin. Mémoire de DEA/FLASH/UNB, 61 p.

8. Boko, M. (1988). Climats et communautés rurales du Bénin : rythmes climatiques et rythmes de développement. Thèse d’état ès-lettres. Université de Bourgogne. 2 tomes. 607p.

9. Dagba, L. (1986). Problèmes de la production halieutique du "lac"' Ahémé (RPB). Influence des activités anthropiques sur la population en poissons et sur la conservation des ressources naturelles. Thèse d'Ingénieur agronome, 164 p. 
10. Gbaguidi, A. (1971). Statistiques des pêches continentales. Année 1990. Service Etude et Statistique de PPL., Cotonou; 128 p.

11. Gboni, M. (1995). Rythme climatique et productions halieutiques au Bénin: le cas de la lagune côtière. Mémoire de maîtrise. DGAT/UNB, $124 \mathrm{p}$.

12. Gnélé, G. (1991). La place du complexe fluvio-lagunaire du BasMono dans l’évolution socio-économique de la région de GrandPopo, 85 p.

13. Gortworst, J. \& Slootweg, R. (1994). Fonctions, valeurs, indicateurs et normes environnementales, 18p

14. Houadegla, W. (1991). Rythmes climatiques et productions halieutiques au Bénin : cas du “'lac” Nokoué. Mémoire de maîtrise DGAT/FLASH/UNB;126 p.

15. Imorou Toko, I., Fiogbe, E. D., Kestemont, P. (2008). Determination of appropriate age and stocking density of vundu larvae, Heterobranchus longifilis (Valenciennes 1840), at the weaning time Aquacult. Res. 39: 24-32.

16. Kestemont, P., Xueliang, X., Hamza, N., Maboudou, J., Imorou Toko, I. (2007). Effect of weaning age and diet on pikeperch larviculture. Aquaculture 264, 197-204.

17. Lalèyè, Ph. (1997). Inventaire des poissons menacés de disparition du Bénin. Rapport d’étude. 95p.

18. Oyédé, L. M. (1991). Dynamique sédimentaire actuelle et messages enregistrés dans les séquences quartenaires et néogènes du domaine margino littoral du Bénin (l'Afrique de l'Ouest). Thèse présentée pour l'obtention du doctorat en géologie sédimentaire, nouveau régime. Université de Bourgogne, Paris ; 302 p.

19. PAE (1996). Enquêtes Villageoises Tome VI, 67 p.

20. Pérard, J., Camberlin, P. \& Amoussou, E. (2007). Influence des lâchers d'eau du barrage de Nangbéto dans la dynamique morphologique de la basse vallée du fleuve Mono (Afrique de l'Ouest). In Actes colloque 'Climat, Tourisme et Environnement'. XXème colloque de l'Association Internationale de Climatologie (AIC), Carthage, Tunisie, pp 471-477.

21. Pliya, J. (1980). La pêche dans le Sud-Ouest du Bénin. Etude de géographie appliquée sur la partie continentale et maritime. AGECOOP, Paris, 293 p.

22. Policar, T., Stejskal, V., Kristan, J., Podhorec, P., Svinger, V., Blaha, M. (2013).The effect of fish size and density on the weaning success in pond-cultured pikeperch (Sander lucioperca L.) juveniles. Aquaculture International: DOI 10.1007/s10499-012- 9563-z. 
23. Totin, V. S. H., Amoussou, E. \& Boko, M. (2006). Stratégies d'amélioration de la productivité halieutique en milieu lagunolacustre au sud-Bénin. In : Revue Sciences de l'Environnement, $\mathrm{n}^{\circ}$ 002, ISSN 1812-1403. Lomé (Togo), pp. 29-45. 